\title{
A Pentapeptide with Tyrosine Moiety as Fluorescent Chemosensor for Selective Nanomolar-Level Detection of Copper(II) Ions
}

\author{
Krzysztof Żamojć ${ }^{1, *(D)}$, Dominik Kamrowski ${ }^{1}$, Magdalena Zdrowowicz ${ }^{1}$, \\ Dariusz Wyrzykowski ${ }^{1}$, Wiesław Wiczk ${ }^{1}{ }^{1}$, , Lech Chmurzyński ${ }^{1}$ and Joanna Makowska ${ }^{1} \mathbb{C}$ \\ Faculty of Chemistry, University of Gdańsk, Wita Stwosza 63, 80-308 Gdańsk, Poland; \\ dominik.kamrowski@gmail.com (D.K.); magdalena.zdrowowicz@ug.edu.pl (M.Z.); \\ dariusz.wyrzykowski@ug.edu.pl (D.W.); wieslaw.wiczk@ug.edu.pl (W.W.); lech.chmurzynski@ug.edu.pl (L.C.); \\ joanna.makowska@ug.edu.pl (J.M.) \\ * Correspondence: krzysztof.zamojc@ug.edu.pl; Tel.: +48-58-523-50-57
}

Received: 27 November 2019; Accepted: 21 January 2020; Published: 23 January 2020 updates

\begin{abstract}
Herein, we have investigated principally with the use of UV and fluorescence (steady-state and time-resolved) spectroscopy the interactions between selected pentapeptides with tyrosine residue (EYHHQ, EHYHQ, EHHQY, and KYHHE) and various metal ions $\left(\mathrm{Cu}^{2+}, \mathrm{Mn}^{2+}, \mathrm{Co}^{2+}, \mathrm{Ni}^{2+}\right.$, $\mathrm{Zn}^{2+}, \mathrm{Cr}^{3+}, \mathrm{Cd}^{2+}, \mathrm{Ag}^{+}, \mathrm{Pb}^{2+}, \mathrm{Sr}^{2+}, \mathrm{Ba}^{2+}, \mathrm{Ca}^{2+}, \mathrm{Mg}^{2+}, \mathrm{Al}^{3+}, \mathrm{Fe}^{2+}$, and $\left.\mathrm{Ga}^{3+}\right)$ in order to establish the relationship between the position of a tyrosine residue in the peptide sequence and the metal ion-binding properties. Among the peptides studied, EHYHQ was evaluated as an efficient and selective ligand for developing a chemosensor for the detection of copper(II) ions. While significant fluorescence emission quenching was observed for that peptide in the presence of $\mathrm{Cu}^{2+}$ cations, other metal cations used at the same and at considerably higher concentrations caused a negligible change of the fluorescence emission spectrum, indicating a high selectivity of EHYHQ for $\mathrm{Cu}^{2+}$ ions. Under optimum conditions, fluorescence intensity was inversely proportional to the concentration of $\mathrm{Cu}^{2+}$ ions. The limit of detection of $\mathrm{Cu}^{2+}$ ions with the use of EHYHQ was determined at the level of $26.6 \mathrm{nM}$. The binding stoichiometry of the complexes of the studied peptides with $\mathrm{Cu}^{2+}$ ions was evaluated spectrophotometrically and fluorimetrically (as in the case of EHYHQ confirmed by mass spectrometry) and found to be 1:2 $\left(\mathrm{Cu}^{2+}\right.$-peptide) for all the investigated systems. Furthermore, the stability constant $(K)$ values of these complexes were determined. The reversibility of the proposed $\mathrm{Cu}^{2+}$ ions sensor was confirmed, the $\mathrm{pH}$ range where the sensor acts was determined, while its analytical performance was compared with some other reported recently fluorescent sensors. The mechanism of the interactions between EHYHQ and $\mathrm{Cu}^{2+}$ was proposed on the basis of NMR spectroscopy investigations.
\end{abstract}

Keywords: $\mathrm{Cu}^{2+}$ ions; fluorescent chemosensor; pentapeptides; fluorescence quenching

\section{Introduction}

In recent years, there has been a particular emphasis on the development of new highly selective molecular sensors for cations with biological interest (such as $\mathrm{Na}^{+}, \mathrm{Ca}^{2+}, \mathrm{Cu}^{2+}$, and $\mathrm{Zn}^{2+}$ ) because of their potential applications to clinical biochemistry and environmental research [1]. Among these ions, the $\mathrm{Cu}^{2+}$, ion as the third most abundant essential transition metal in a human organism [2], plays a significant role in a variety of fundamental physiological processes (many proteins use $\mathrm{Cu}^{2+}$ ion as a cofactor for electron or oxygen transport as well as a catalyst for oxidation-reduction reactions [3]). The imbalance in the level of free copper ions can have a pernicious influence on 
biological systems-their deficiency is the symptom of anemia [4]. On the other hand, when the levels of $\mathrm{Cu}^{2+}$ ions exceed cellular needs (the concentration of copper in blood is expected to lie between 11.8 and $23.6 \mu \mathrm{M}$ [5]), they catalyze the generation of reactive oxygen and nitrogen species that can damage lipids, nucleic acids, and proteins [6]. Furthermore, disorders in cellular homeostasis of $\mathrm{Cu}^{2+}$ ions have been proven to result in various diseases, such as Alzheimer's disease, Parkinson's disease, prion diseases, or amyotrophic lateral sclerosis [7]. Because of its wide applications, $\mathrm{Cu}^{2+}$ ion is also attributed as a significant metal pollutant. The US Environmental Protection Agency set the limit of copper in drinking water at $1.3 \mathrm{ppm}(\sim 20 \mu \mathrm{M})[6]$.

Considering all the above reasons, there has been a growing interest in the analytical detection of $\mathrm{Cu}^{2+}$ ions using, for example, colorimetry [8,9], spectrophotometry [10], laser ablation inductively coupled plasma mass spectrometry [11], flame atomic absorption spectrometry [12], and voltammetry [13]. Although all these methods provide relatively low limits of detection and wide concentration ranges, many of them are destructive techniques that require the use of expensive equipment, making them not adaptable for online monitoring. Therefore, the development of fluorescent chemosensors (due to high sensitivity of fluorescence spectroscopy, easy operation, visual simplicity [14], instantaneous response, real-time detection [15], and a variety of fluorophores [16]) for the detection of $\mathrm{Cu}^{2+}$ ions is of great importance [17]. On the other hand, the availability of a variety of fluorophores and the selectivity of such fluorescent probes still remain a great challenge, as many recently reported chemosensors for cations demonstrated a change in their fluorescent features after binding with more than one ion [18-20].

Studies of the complexes of amino acids and peptides with metal ions have been performed with a main goal to better understand transition metal complexes in proteins [21,22]. For instance, it has been shown that several ions, e.g., $\mathrm{Cu}^{2+}$ and $\mathrm{Zn}^{2+}$, are involved in the amyloid- $\beta$ peptide aggregation process, which presumably plays a main role in Alzheimer's disease [23]. From among all amino acids present in the amyloid- $\beta$ (1-42) peptide sequence, histidine and tyrosine side chains are proven to have a distinct affinity for $\mathrm{Cu}^{2+}$ and other metal cations [24]. The main goal of our work was to investigate the interactions between selected pentapeptides with a tyrosine moiety including EYHHQ, EHYHQ, EHHQY, and KYHHE, where E denotes glutamate, Y tyrosine, $\mathrm{H}$ histidine, $\mathrm{Q}$ glutamine, $\mathrm{K}$ lysine (structures of these pentapeptides are shown in Figure S1 in the Supplementary Materials), and a list of chosen metal ions $\mathrm{Cu}^{2+}, \mathrm{Mn}^{2+}, \mathrm{Co}^{2+}, \mathrm{Ni}^{2+}, \mathrm{Zn}^{2+}, \mathrm{Cr}^{3+}, \mathrm{Cd}^{2+}, \mathrm{Ag}^{+}, \mathrm{Pb}^{2+}, \mathrm{Sr}^{2+}, \mathrm{Ba}^{2+}, \mathrm{Ca}^{2+}, \mathrm{Mg}^{2+}$, $\mathrm{Al}^{3+}, \mathrm{Fe}^{2+}$, and $\mathrm{Ga}^{3+}$ ) to evaluate the relationship between the position of a tyrosine residue in the pentapeptide sequence and the metal ion-binding properties.

\section{Results and Discussion}

In order to establish the metal ion-binding properties of the studied peptides, UV absorption spectra of $0.1 \mathrm{mM}$ EYHHQ, EHYHQ, EHHQY, and KYHHE in $5 \mathrm{mM}$ MES buffer (pH 6.0) were recorded in the absence and in the presence of $80 \mu \mathrm{M}$ of various metal ions (molar ratio 1:0.8), including $\mathrm{Cu}^{2+}$, $\mathrm{Mn}^{2+}, \mathrm{Co}^{2+}, \mathrm{Ni}^{2+}, \mathrm{Zn}^{2+}, \mathrm{Cr}^{3+}, \mathrm{Cd}^{2+}, \mathrm{Ag}^{+}, \mathrm{Pb}^{2+}, \mathrm{Sr}^{2+}, \mathrm{Ba}^{2+}, \mathrm{Ca}^{2+}, \mathrm{Mg}^{2+}, \mathrm{Al}^{3+}, \mathrm{Fe}^{2+}$, and $\mathrm{Ga}^{3+}$, and are shown in Figure 1. It can be observed that the addition of only $\mathrm{Cu}^{2+}$ ions $(80 \mu \mathrm{M})$ promoted a $1.5 \times$ enhanced response at $275 \mathrm{~nm}$ and even higher at $<275 \mathrm{~nm}$ compared to other metal ions. This can also be observed as a rapid (a few seconds) response. A noticeable change in the shape of the spectra and intensity of the absorbance are arguments supporting the formation of a new chemical species. As no other metal ion/peptide systems showed any significant changes in their absorption features compared to that of $\mathrm{Cu}^{2+}$ as well as taking into consideration an evidenced stronger affinity of various peptides for $\mathrm{Cu}^{2+}$ ions (when compared to other metal ions) [25-27], we have assumed the observed result for $\mathrm{Cu}^{2+}$ to have arisen from the chelation of $\mathrm{Cu}^{2+}$ ions with the peptides under study [28-31]. Furthermore, no shift of the band with a maximum at $275 \mathrm{~nm}$ (as can be observed, for example, in Figure 1b) indicates that a reformed new excited electronic state of tyrosine in a complex is similar to the one in a ligand alone [32]. It is noteworthy to mention that an increase in the absorbance was observed until the peptides were saturated at approximately 0.5 molar equivalent of added $\mathrm{Cu}^{2+}$ and 
that subsequent addition of excess $\mathrm{Cu}^{2+}$ ions produced no significant changes in UV spectra (details will be described further and shown in Figure 3).
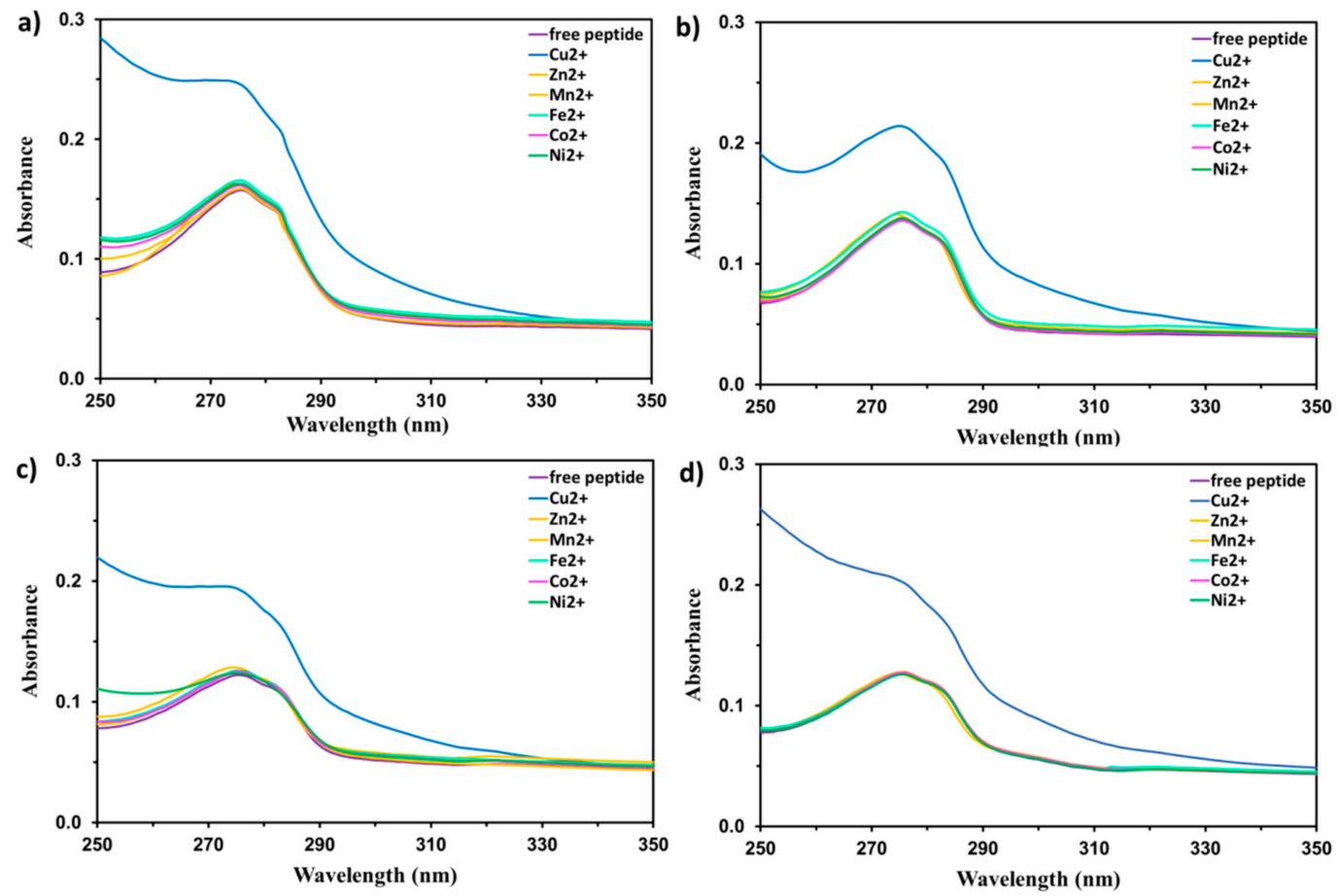

Figure 1. The UV absorption spectra of EYHHQ (a), EHYHQ (b), EHHQY (c), and KYHHE (d) (0.1 mM in 5 mM MES buffer, $\mathrm{pH}$ 6.0) in the absence of any ions (free peptide) as well as in the presence of $\mathrm{Cu}^{2+}$ and other cations $\left(80 \mu \mathrm{M}\right.$, molar ratio 1:0.8) including $\mathrm{Mn}^{2+}, \mathrm{Fe}^{2+}, \mathrm{Co}^{2+}, \mathrm{Ni}^{2+}$, and $\mathrm{Zn}^{2+}$.

To further explore the selectivity of the studied peptides toward metal ions, their fluorescence emission spectra were also recorded upon excitation at $275 \mathrm{~nm}$ in the presence of $80 \mu \mathrm{M}$ of various metal ions (molar ratio 1:0.8), including $\mathrm{Cu}^{2+}, \mathrm{Mn}^{2+}, \mathrm{Co}^{2+}, \mathrm{Ni}^{2+}, \mathrm{Zn}^{2+}, \mathrm{Cr}^{3+}, \mathrm{Cd}^{2+}, \mathrm{Ag}^{+}, \mathrm{Pb}^{2+}, \mathrm{Sr}^{2+}, \mathrm{Ba}^{2+}$, $\mathrm{Ca}^{2+}, \mathrm{Mg}^{2+}, \mathrm{Al}^{3+}, \mathrm{Fe}^{2+}$, and $\mathrm{Ga}^{3+}$, immediately after the addition of each ion and mixing the solution. The results are shown in Figure 2. The obtained results indicated that $\mathrm{Cu}^{2+}$ was the sole cation that contributed to an efficient and rapid fluorescence quenching of all studied peptides. However, in the cases of EHHQY, EYHHQ, and KYHHE (contrary to EHYHQ), the addition of $\mathrm{Ni}^{2+}$ ions led to a very slow but indisputable (approximately 6\%) decrease in the fluorescence intensity. We are using this as an evidence for very slow binding of $\mathrm{Ni}^{2+}$ ions to EHHQY, EYHHQ, and KYHHE but, at the same time, not to EHYHQ. Indeed, additional spectrophotometric experiments revealed that EHYHQ (in contrast to EHHQY, EYHHQ, and KYHHE) does not interact with $\mathrm{Ni}^{2+}$ ions (Figure $\mathrm{S} 2$ in the Supplementary Materials). Hence, an exceptional, significant (approximately 3.5 times in the presence of $50 \mu \mathrm{M}$ of metal ion) and very fast (few seconds) decrease in the fluorescence intensity of EHYHQ caused only by $\mathrm{Cu}^{2+}$ ions indicated its specific sensing ability to these cations. It is worth to mention that (similarly to absorbance measurements) an increase in the fluorescence quenching was observed until EHYHQ was saturated at approximately 0.5 molar equivalent of added $\mathrm{Cu}^{2+}$, and subsequent addition of the metal ion produced no further quenching (details will be described further and shown in Figure 3). One of the most probable reasons responsible for the observed phenomenon is the formation of a nonfluorescent $\mathrm{Cu}^{2+}$-peptide complex due to a chelation enhancement quenching effect [33] or/and ligand to metal charge transfer [34-36]. The presence of a paramagnetic $\mathrm{d}^{9} \mathrm{Cu}^{2+}$ ion in the proximity of a tyrosine residue makes that, in each complex, the forbidden intersystem crossing becomes faster (paramagnetic effect) $[17,33]$. As a result, the studied complexes after excitation undergo intersystem crossing from $S_{1}$ to $\mathrm{T}_{1}$ state of the fluorophore that is further deactivated by bimolecular non-radiative processes. 

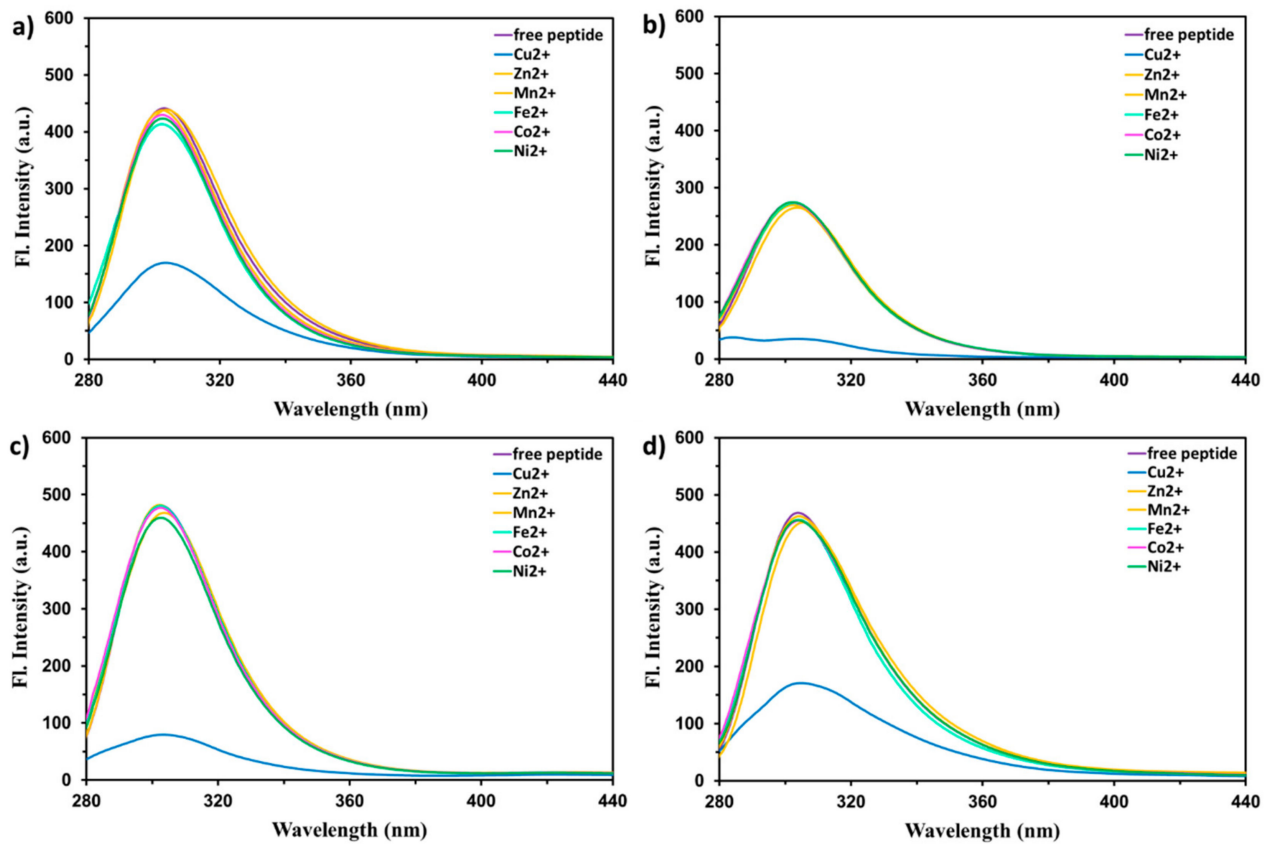

Figure 2. The fluorescence emission spectra of EYHHQ (a), EHYHQ (b), EHHQY (c), and KYHHE (d) (0.1 $\mathrm{mM}$ in $5 \mathrm{mM}$ MES buffer, $\mathrm{pH}$ 6.0) in the absence of any ions (free peptide) as well as in the presence of $\mathrm{Cu}^{2+}$ and other cations $\left(80 \mu \mathrm{M}\right.$, molar ratio 1:0.8) including $\mathrm{Mn}^{2+}, \mathrm{Fe}^{2+}, \mathrm{Co}^{2+}, \mathrm{Ni}^{2+}$, and $\mathrm{Zn}^{2+}$.
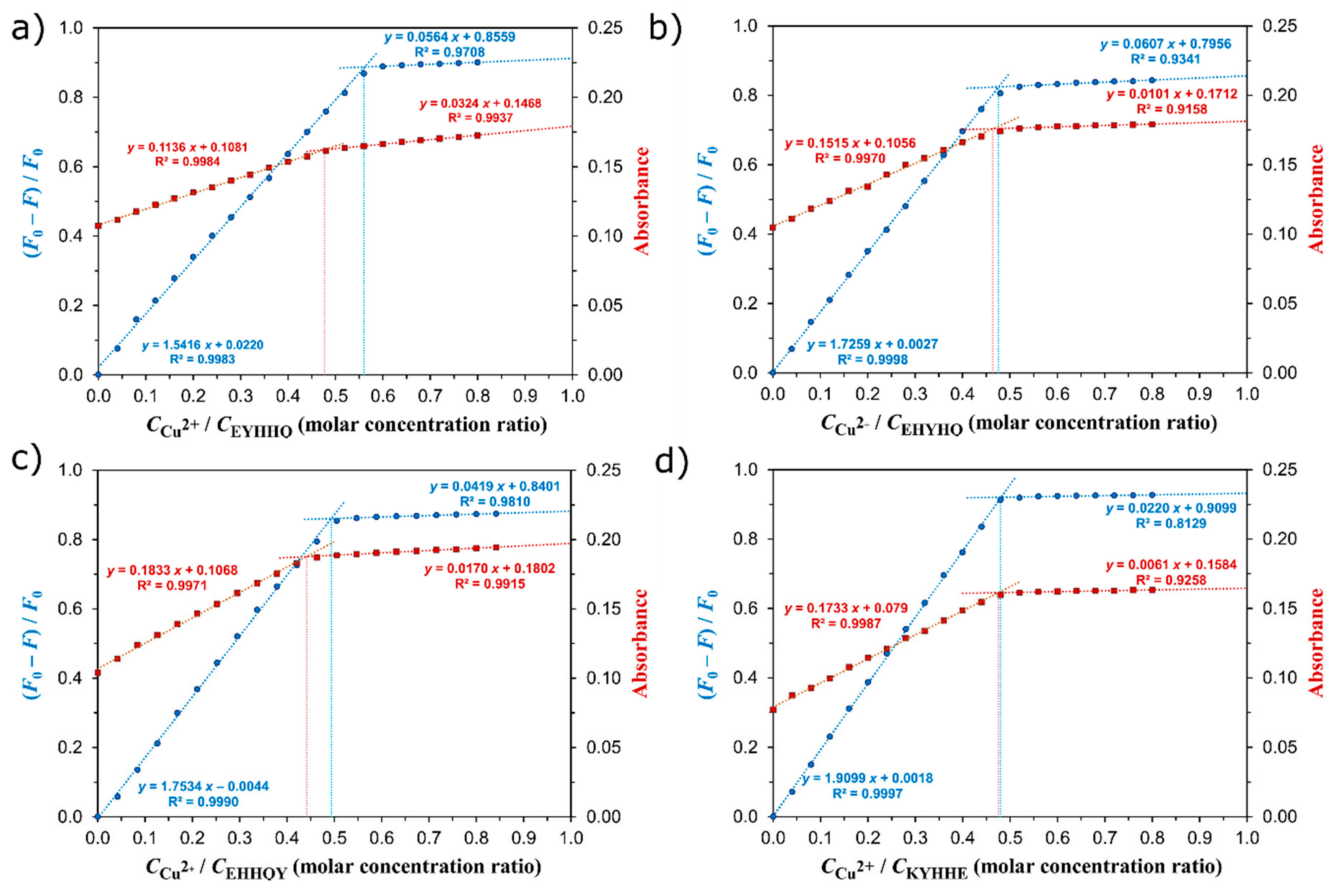

Figure 3. The plots of $\frac{\mathrm{F}_{0}-\mathrm{F}}{\mathrm{F}_{0}}$ (blue) and absorbance measured at $275 \mathrm{~nm}$ (red) against the metal ion to peptide molar concentration ratio $\left(\frac{\mathrm{c}_{\mathrm{Cu}^{2+}}}{\mathrm{c}_{\mathrm{peptide}}}\right)$ for EYHHQ (a), EHYHQ (b), EHHQY (c), and KYHHE (d); $c_{\text {peptide }}=0.1 \mathrm{mM}$ : Line-line intersections represent the stoichiometry of the formed $\mathrm{Cu}^{2+}$-peptide complexes. $F_{0}$ is fluorescence intensity (measured at $305 \mathrm{~nm}, \lambda_{\mathrm{ex}}=275 \mathrm{~nm}$ ) of the peptide in the absence of $\mathrm{Cu}^{2+}$ ions; $\mathrm{F}$ is fluorescence intensity (measured at $305 \mathrm{~nm}, \lambda_{\mathrm{ex}}=275 \mathrm{~nm}$ ) of the peptide at any given concentration of $\mathrm{Cu}^{2+}$ ions.

UV absorption and fluorescence titration experiments of EYHHQ, EHYHQ, EHHQY, and KYHHE $(0.1 \mathrm{mM})$ with $\mathrm{Cu}^{2+}$ ions $(0-80 \mu \mathrm{M})$ in $5 \mathrm{mM}$ MES buffer $(\mathrm{pH} 6.0)$ were also carried out in order to 
establish the binding stoichiometry of the formed complexes as well as to determine appropriate stability constant $(K)$ values. The binding stoichiometry of the resulting complexes was evaluated according to commonly used Yoe and Jones' method [37]. According to this method, the analytical signals measured (in our experiment, these are (i) $\frac{F_{0}-F}{F_{0}}$, where $F_{0}$ denotes fluorescence intensity (measured at $305 \mathrm{~nm}, \lambda_{\mathrm{ex}}=275 \mathrm{~nm}$ ) of the peptide in the absence of $\mathrm{Cu}^{2+}$ ions while $\mathrm{F}$ denotes fluorescence intensity (measured at $305 \mathrm{~nm}, \lambda_{\mathrm{ex}}=275 \mathrm{~nm}$ ) of the peptide at any given concentration of $\mathrm{Cu}^{2+}$ ions, and (ii) absorbance measured at $275 \mathrm{~nm}$ ) were plotted versus the corresponding molar concentration ratio $\frac{{ }^{\mathrm{C}} \mathrm{Cu}^{2+}}{\mathrm{C}_{\text {peptide }}}$, and appropriate curves were obtained. Subsequently, the stoichiometry of the complexes was estimated from the points where these curves changed their slopes (Figure 3). As these results revealed unequivocally that the complexes of the stoichiometry of 1:2 $\left(\mathrm{Cu}^{2+}\right.$ to peptide) are formed for all the investigated systems, the equilibrium model presented in Table 1 was applied to calculate the stability constants of the complexes under study using the HypSpec program [38].

Table 1. $\log K$ values (standard deviation in parentheses) for the $\mathrm{Cu}^{2+}$-peptide complexes in $5 \mathrm{mM}$ MES buffer solution ( $\mathrm{pH}$ 6.0) calculated for $\mathrm{T}=25^{\circ} \mathrm{C}$ : $\mathrm{Cu}$ and $\mathrm{P}$ denote the $\mathrm{Cu}^{2+}$ ion and the peptide, respectively (the charges are omitted for the sake of clarity). Twenty-two data points were used to estimate each standard deviation $(n=22)$.

\begin{tabular}{cccccc}
\hline Reaction & $\log K_{n}$ & $\mathrm{Cu}^{2+}$-EYHHQ & $\mathrm{Cu}^{2+}$-EHYHQ & $\mathrm{Cu}^{2+}$-EHHQY & $\mathrm{Cu}^{2+}$-KYHHE \\
\hline $\mathrm{Cu}+\mathrm{P}=\mathrm{CuP}$ & $\log K_{1}$ & $1.48( \pm 0.03)$ & $1.25( \pm 0.01)$ & $1.55( \pm 0.01)$ & $1.46( \pm 0.01)$ \\
$\mathrm{CuP}+\mathrm{P}=\mathrm{CuP}_{2}$ & $\log K_{2}$ & $3.34( \pm 0.08)$ & $3.25( \pm 0.02)$ & $3.34( \pm 0.02)$ & $2.55( \pm 0.05)$ \\
$\mathrm{Cu}+2 \mathrm{P}=\mathrm{CuP}_{2}$ & $\log K$ & $4.82( \pm 0.04)$ & $4.50( \pm 0.01)$ & $4.89( \pm 0.01)$ & $( \pm 0.01)$ \\
\hline
\end{tabular}

To estimate the sensing ability and selectivity of EHYHQ toward $\mathrm{Cu}^{2+}$ ions, we have carried out competitive experiments, where the peptide was exposed to various metal cations separately $\left(\mathrm{Mn}^{2+}\right.$, $\mathrm{Co}^{2+}, \mathrm{Ni}^{2+}, \mathrm{Zn}^{2+}, \mathrm{Cr}^{3+}, \mathrm{Cd}^{2+}, \mathrm{Ag}^{+}, \mathrm{Pb}^{2+}, \mathrm{Sr}^{2+}, \mathrm{Ba}^{2+}, \mathrm{Ca}^{2+}, \mathrm{Mg}^{2+}, \mathrm{Al}^{3+}$, and $\mathrm{Ga}^{3+}$ ) and then to $\mathrm{Cu}^{2+}$ ions (Figure 4). The fluorescence of $0.1 \mathrm{mM}$ of EHYHQ in the $5 \mathrm{mM}$ MES buffer was firstly evaluated in the absence of any ions, then in the presence of each potentially interfering ion $(0.25 \mathrm{mM})$, and finally in the presence of a mixture of potentially interfering ion $(0.25 \mathrm{mM})$ and $\mathrm{Cu}^{2+}(0.05 \mathrm{mM})$. The obtained results revealed that only $\mathrm{Cu}^{2+}$ ions induced a significant decrease in the fluorescence intensity of EHYHQ at $305 \mathrm{~nm}$, while under the action of other ions (used at concentrations five times higher than $\mathrm{Cu}^{2+}$ ions), there were no changes observed or the fluorescence quenching was negligible. Furthermore, the decrease in the fluorescence intensity of EHYHQ in the presence of a mixture of $\mathrm{Cu}^{2+}, \mathrm{Mn}^{2+}, \mathrm{Fe}^{2+}$, $\mathrm{Co}^{2+}, \mathrm{Ni}^{2+}$, and $\mathrm{Zn}^{2+}$ (each $80 \mu \mathrm{M}$ ) was comparable (within the range of experimental error) with that observed for $80 \mu \mathrm{M}$ of $\mathrm{Cu}^{2+}$ ions alone (Figure S3 in the Supplementary Materials). All these results demonstrated the good anti-interference ability of EHYHQ to other cations. It consequently permitted highly selective detection and determination of $\mathrm{Cu}^{2+}$ ions in aqueous solutions with the use of that peptide. 


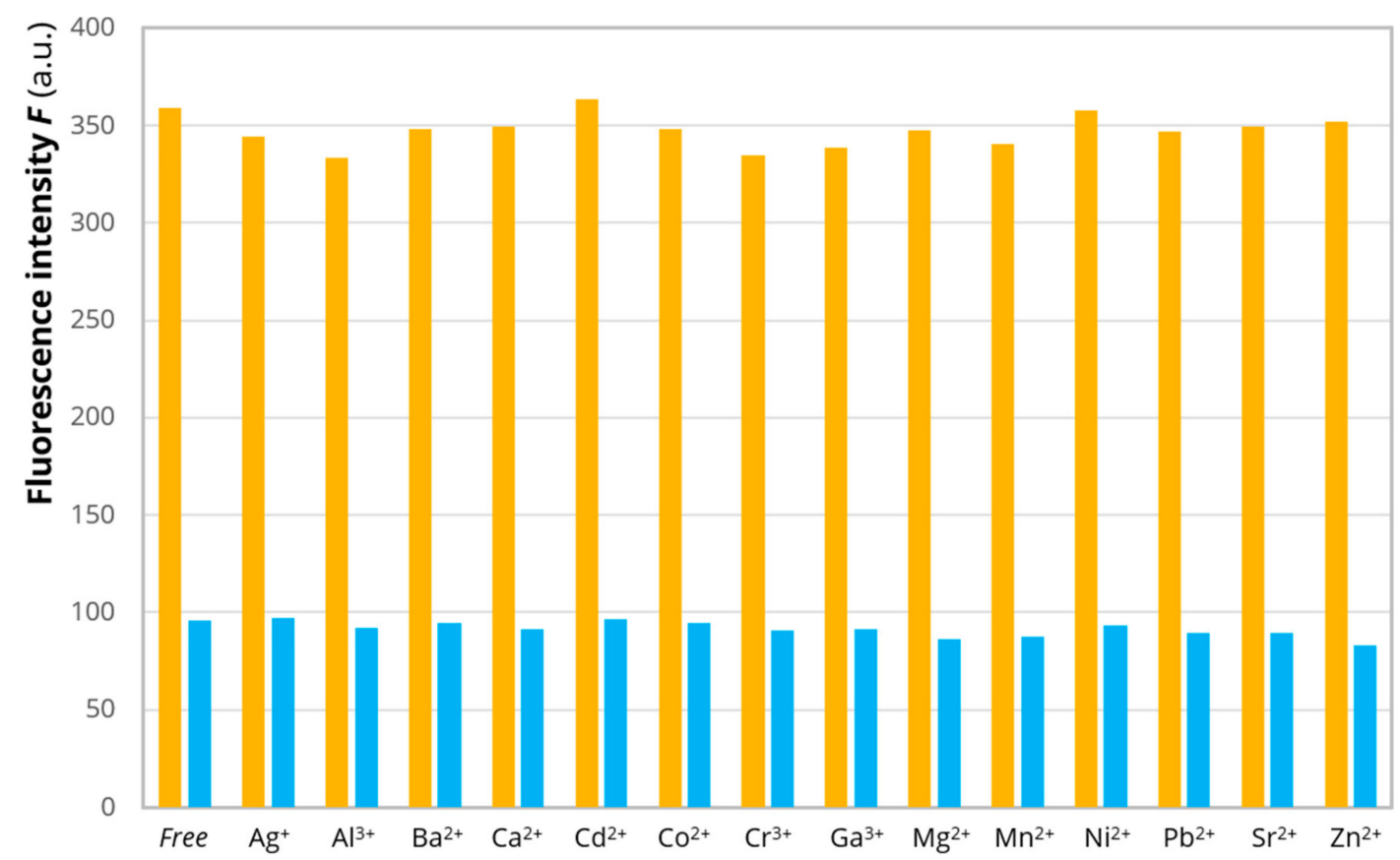

Figure 4. The fluorescence intensity (measured at $305 \mathrm{~nm}$ ) of EHYHQ $(0.1 \mathrm{mM})$ with the addition of $0.25 \mathrm{mM}$ of various metal ions (orange columns) in $5 \mathrm{mM}$ MES buffer ( $\mathrm{pH}$ 6.0) and then with the addition of $0.05 \mathrm{mM}$ of $\mathrm{Cu}^{2+}$ ions (blue columns): Molar ratio 1:2.5:0.5 (EHYHQ to $\mathrm{Me}^{\mathrm{n}+}$ to $\mathrm{Cu}^{2+}$ ).

Figure 5 shows the linear plot of $\frac{\mathrm{F}_{0}}{\mathrm{~F}}$ for EHYHQ as a function of the concentration of $\mathrm{Cu}^{2+}$ ions that fits the Stern-Volmer equation, suggesting that only one type of quenching (either dynamic or either static) is involved in the fluorescence intensity decrease. It revealed that the extent of the fluorescence quenching is proportional to the concentration of $\mathrm{Cu}^{2+}$ ions over the range of 79.9-792 nM, which forms the basis of the method for the $\mathrm{Cu}^{2+}$ determination. The inset of Figure 5 tabulates the analytical parameters obtained for the calibration graph reflecting the determination of $\mathrm{Cu}^{2+}$ ions with the use of EHYHQ as a fluorescent sensor. In the presence of EHYHQ as a ligand, the limit of detection (LOD) of $\mathrm{Cu}^{2+}$ was estimated to be less than $27 \mathrm{nM}$, which is $\sim 750$ times lower than the recommended maximum contaminant level for these cations in drinking water [6]. Within the investigated range of quantitation, a linear relationship was observed (between the relative fluorescence decrease and the concentration of $\mathrm{Cu}^{2+}$ ions) - as it is evidenced by the values of the coefficients of determination $\left(\mathrm{R}^{2}\right)$ close to unity. Furthermore, the determination of $\mathrm{Cu}^{2+}$ ions with the use of EHYHQ is characterized with a high accuracy. 


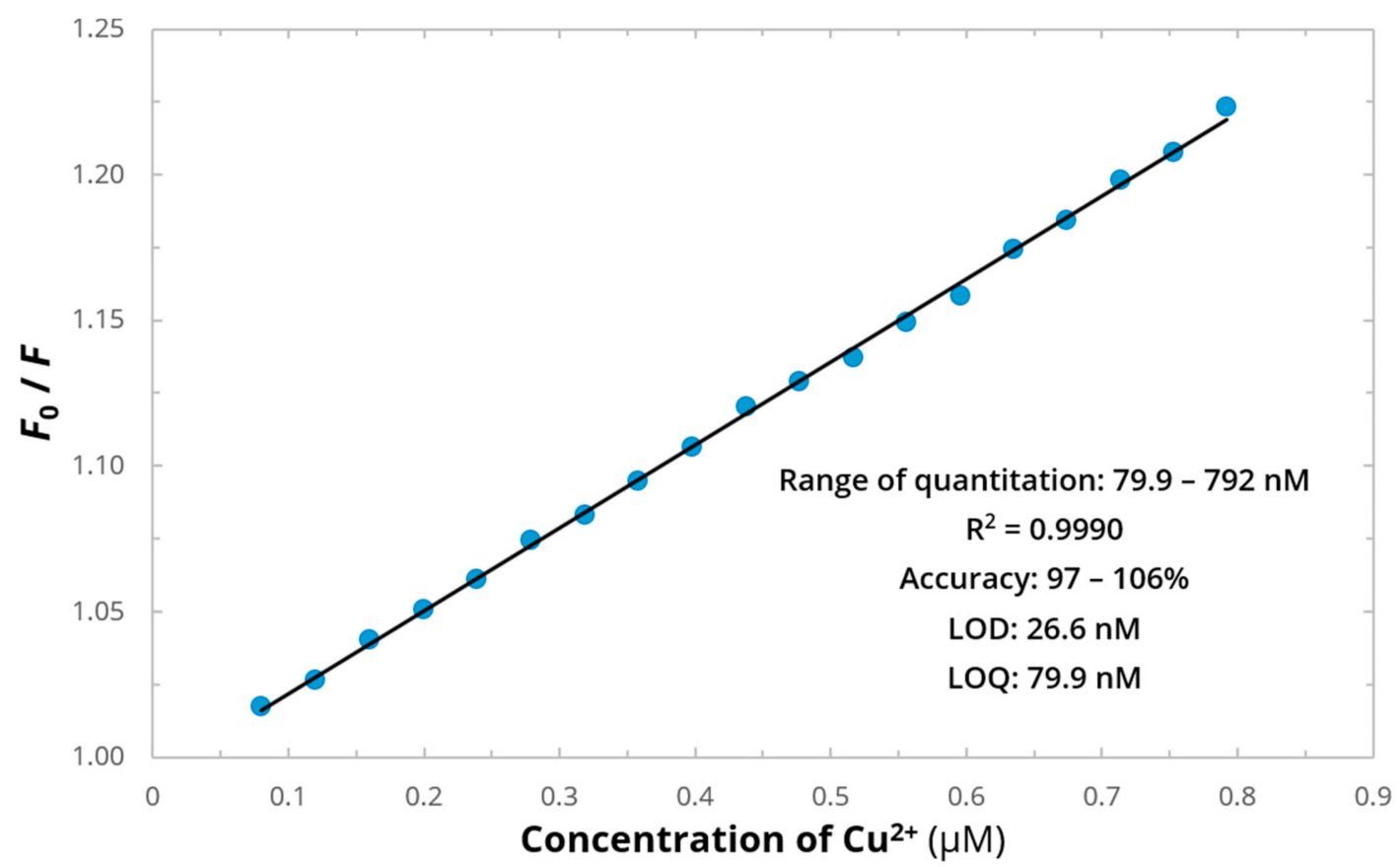

Figure 5. A calibration plot reflecting the relationship between the relative fluorescence decrease of EHYHQ $(0.1 \mathrm{mM})$ and the concentration of $\mathrm{Cu}^{2+}$ ions: the inset gathers analytical characteristics of the graph. $\frac{F_{0}}{F}$ values are shown as a mean value from 30 data points $(n=30)$. LOD—limit of detection; LOQ-limit of quantification.

The determination of fluorescence lifetimes was carried out to confirm that the static quenching is solely responsible for the observed fluorescence decrease. According to performed time-resolved experiments in the case of all peptides under study, the values of their fluorescence lifetimes were constant regardless of the $\mathrm{Cu}^{2+}$ ions concentration and equal to $1.12 \mathrm{~ns}$ for EHHQY, $0.78 \mathrm{~ns}$ for EHYHQ, $0.85 \mathrm{~ns}$ for $\mathrm{EYHHQ}$, and $0.77 \mathrm{~ns}$ for KYHHE. Therefore, since $\mathrm{Cu}^{2+}$ ions had no effect on fluorescence lifetimes of all studied peptides, it could be concluded that the mechanism of fluorescence quenching is purely static. It is in a great agreement with the results shown in Figure 1, as appropriate complex formation very often impacts the absorption spectrum of the fluorophore.

The $\mathrm{pH}$ dependence of the fluorescence emission intensities of EHYHQ $(0.1 \mathrm{mM})$ in the absence and presence of $80 \mu \mathrm{M}$ of $\mathrm{Cu}^{2+}$ ions was examined over a wide range of $\mathrm{pH}$ values. As shown in Figure 6, the determination of $\mathrm{Cu}^{2+}$ ions can work well in the range of $\mathrm{pH}$ approximately 4.0-11.0, where the decrease of fluorescence intensity of EHYHQ under the action of $\mathrm{Cu}^{2+}$ ions is significant. These observations indicate that EHYHQ is a very effective fluorescent sensor for $\mathrm{Cu}^{2+}$ ions under the environmental and physiological conditions.

The reversibility of EHYHQ towards $\mathrm{Cu}^{2+}$ ions was evaluated as shown in Figure $\mathrm{S} 4$ in the Supplementary Materials. When EHYHQ $(0.1 \mathrm{mM}, \mathrm{pH} 7.4)$ is saturated by the addition of $\mathrm{Cu}^{2+}$ ions ( 0.5 equiv.), approximately 3 times decrease in fluorescence intensity is observed. However, upon the addition of $\mathrm{Cu}^{2+}$ chelating agent (2 equiv. of EDTA) to the EHYHQ with $\mathrm{Cu}^{2+}$ solution, a significant increase in the fluorescence intensity was observed. The obtained results clearly demonstrate that $\mathrm{Cu}^{2+}$ ions can be effectively replaced by EDTA from $\mathrm{Cu}^{2+}$-EHYHQ complex and consequently prove that $\mathrm{Cu}^{2+}$ ions recognition is a complexing and reversible process. 


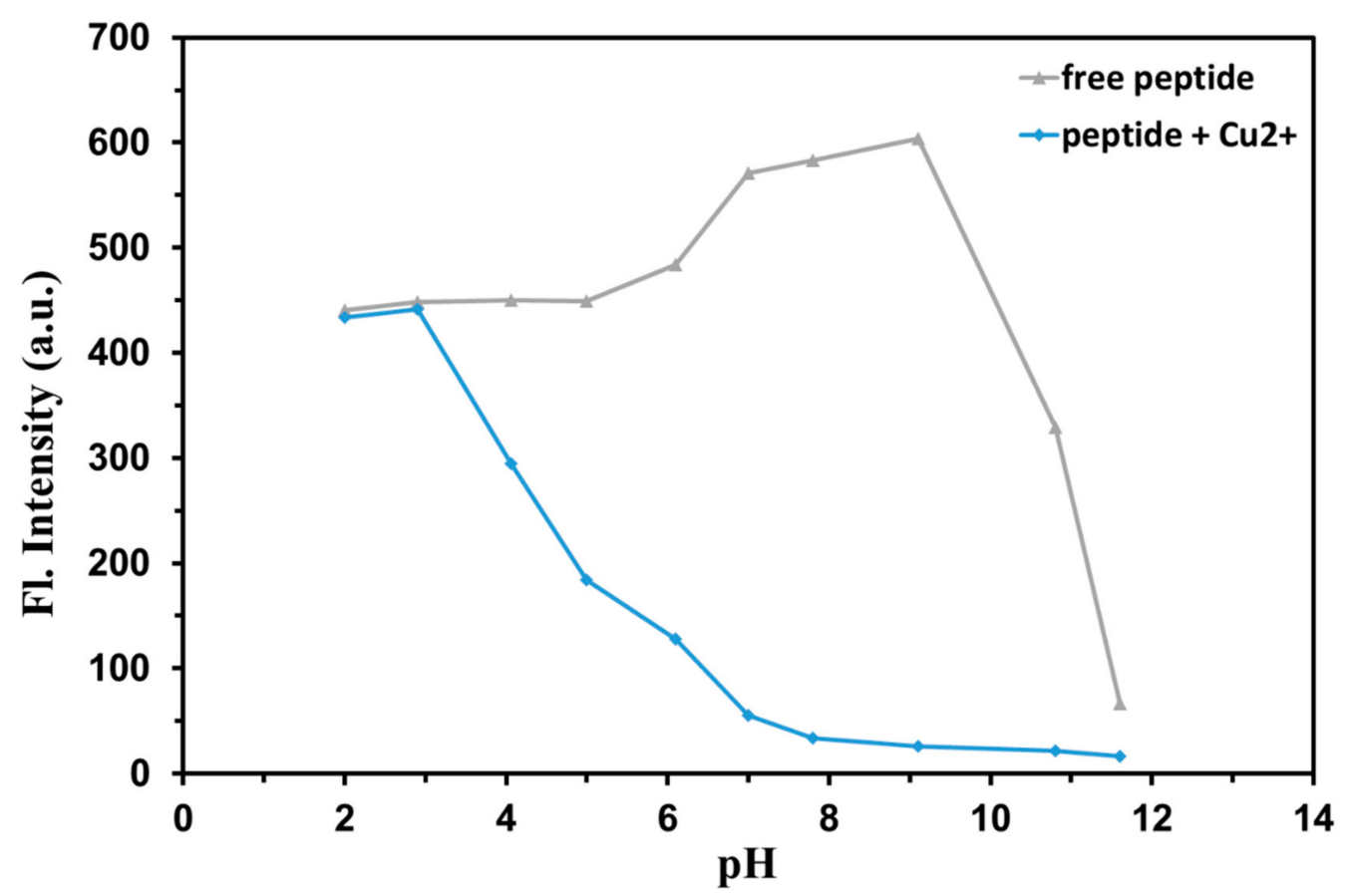

Figure 6. The $\mathrm{pH}$ influence on the fluorescence intensity of EHYHQ $(0.1 \mathrm{mM})$ in the absence and presence of $80 \mu \mathrm{M}$ of $\mathrm{Cu}^{2+}$.

In order to propose the mechanism of interactions between EHYHQ and $\mathrm{Cu}^{2+}$ ions, we have performed additional NMR spectroscopy investigations. Figure 7 shows the effect of the presence of $\mathrm{Cu}^{2+}$ ions on the appearance of the ${ }^{1} \mathrm{H}$ NMR spectrum of EHYHQ. We have observed that the addition of $\mathrm{Cu}^{2+}$ ions to the peptide solution caused no significant change of linewidths and chemical shifts except for aromatic protons of the imidazole ring, but slight line-broadening was observed. This is in good agreement with reports $[39,40]$ that paramagnetic $\mathrm{Cu}^{2+}$ ions are known to broaden ${ }^{1} \mathrm{H} N M R$ signals without any dramatic change in chemical shifts when the ${ }^{1} \mathrm{H}$ is in close vicinity to a cation or on a donor atom directly coordinated to a metal. As the nitrogen atom of the imidazole ring very effectively competes with the terminal amino group as an anchoring point for $\mathrm{Cu}^{2+}$, it strongly points to histidine residues as anchoring sites and to their involvement in complexation [41,42]. As the signals corresponding to protons of glutamine are slightly broadened too, it may demonstrate a participation of that residue (along with histidine) in a complexation as well [43]. Taking into consideration the fact that $\mathrm{Ni}^{2+}$ ions unambiguously interact with EHHQY, EYHHQ, and KYHHE but, at the same time, not with EHYHQ (Figure S2 in the Supplementary Materials), we could assume that both histidine residues placed side by side in a peptide sequence might be responsible for binding properties in the case of that cation. On the other hand, the tyrosine residue placed between histidine residues in the EHYHQ sequence has no influence on the interactions between that peptide and $\mathrm{Cu}^{2+}$ ions. A visualization of predicted structure of complex between EHYHQ and $\mathrm{Cu}^{2+}$ (both cis and trans isomers) is presented in Figure S5 in the Supplementary Materials. 


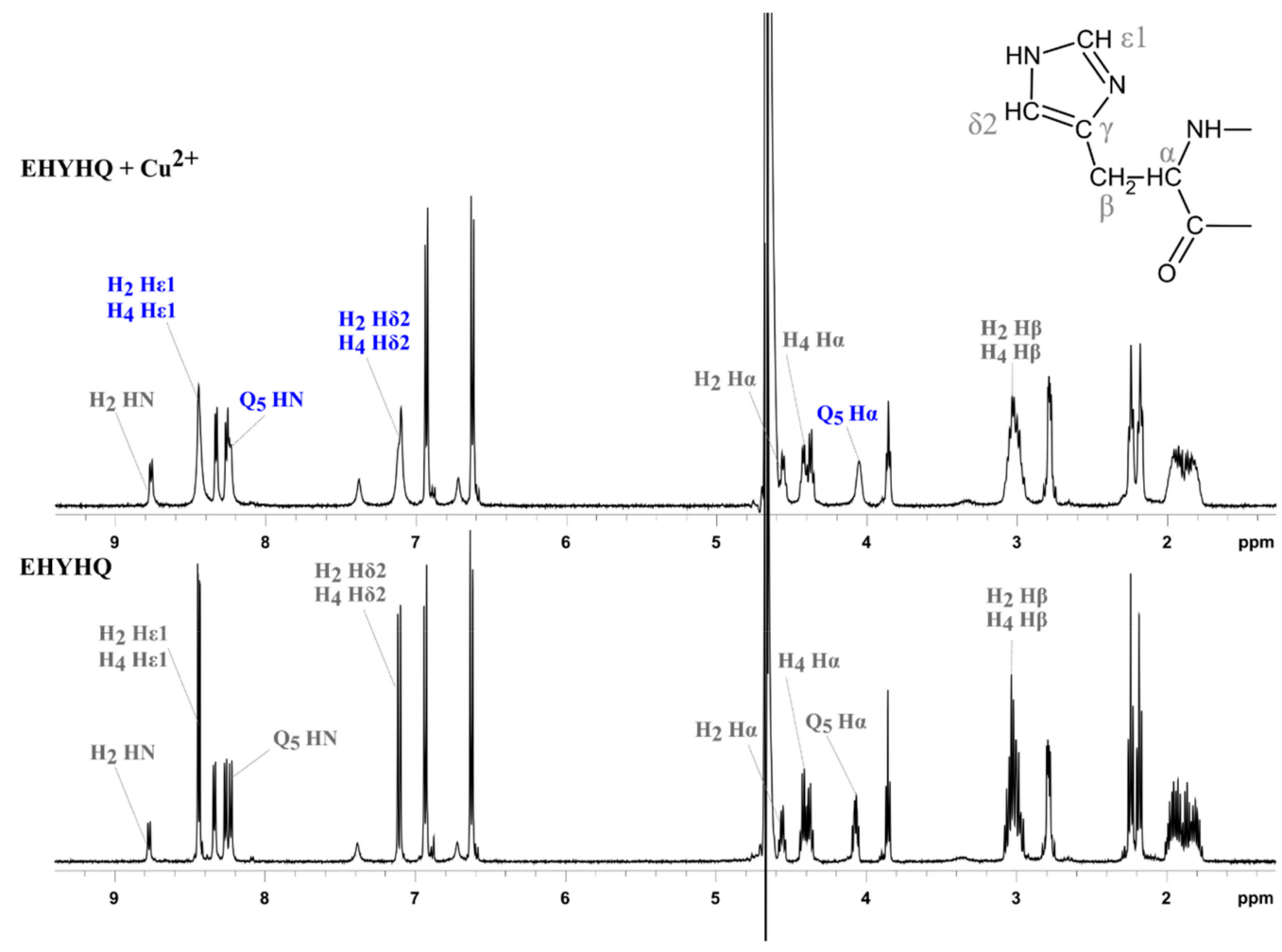

Figure 7. ${ }^{1} \mathrm{H}$ NMR spectrum of $8 \mathrm{mM}$ EHYHQ in the presence of $\mathrm{Cu}^{2+}$ ions in 2:1 molar ratio (upper panel) and in the absence of $\mathrm{Cu}^{2+}$ ions (lower panel) along with selected signals identities: The most significantly broadened signals are marked with blue.

In order to confirm the type of interactions and stoichiometry of the complex formed between EHYHQ and $\mathrm{Cu}^{2+}$ ions, additional MS investigations were performed-EHYHQ in the absence of $\mathrm{Cu}^{2+}$ and in the presence of $\mathrm{Cu}^{2+}$ in ratio 1:5 (peptide to $\mathrm{Cu}^{2+}$ ) were analyzed using a $2 \mathrm{mM}$ solution in water (Figure 8, Figures S6-S8 in the Supplementary Materials, and Table S1 in the Supplementary Materials). The spectrum of pure EHYHQ revealed singly and doubly charged molecular ions with $\mathrm{m} / \mathrm{z} 713.9728$ $\left([\mathrm{M}+\mathrm{H}]^{+}\right)$and $357.5150\left([\mathrm{M}+2 \mathrm{H}]^{2+}\right)$, respectively. Further, the analysis of the EHYHQ- $\mathrm{Cu}^{2+}$ solution (molar ratio 1:5) showed additionally (apart from the signals of $[\mathrm{M}+\mathrm{H}]^{+}$and $[\mathrm{M}+2 \mathrm{H}]^{2+}$ ) molecular ions with $\mathrm{m} / \mathrm{z} 775.9771\left([\mathrm{M}+\mathrm{Cu}]^{+}\right), 744.4875\left([2 \mathrm{M}+\mathrm{Cu}]^{2+}\right)$, and $388.5192\left([\mathrm{M}+\mathrm{Cu}]^{2+}\right)$, respectively. This is in line with the results obtained from the UV and fluorescence spectroscopy measurements and confirms the fact that EHYHQ under experimental conditions binds $\mathrm{Cu}^{2+}$ ions in 2:1 molar. 

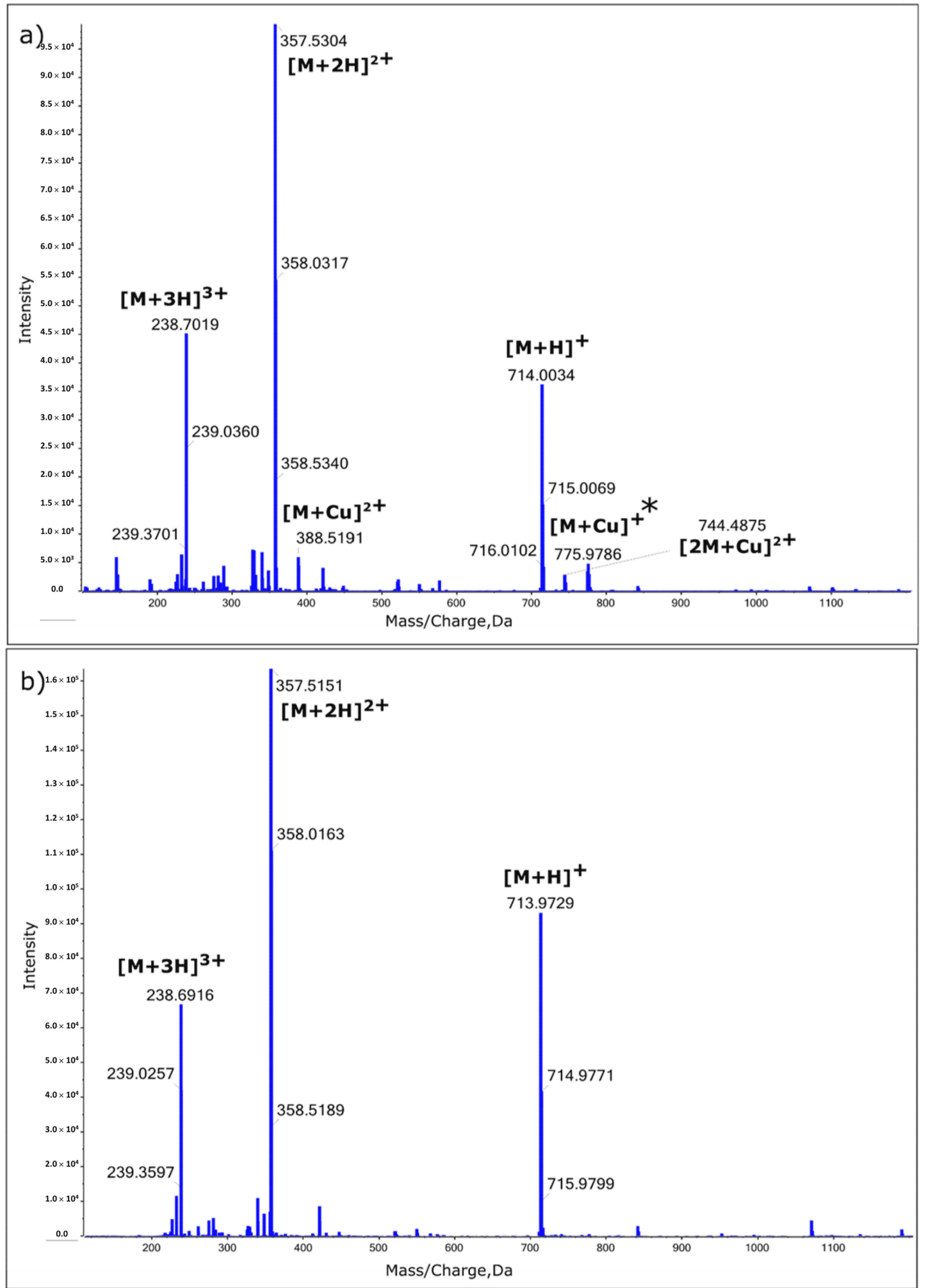

Figure 8. The MS spectra of the $2 \mathrm{mM}$ solutions of EHYHQ in the presence of $10 \mathrm{mM}$ of $\mathrm{Cu}^{2+}$ ions (a) and in the absence of $\mathrm{Cu}^{2+}$ ions $(\mathbf{b}) .{ }^{*} \mathrm{Cu}(\mathrm{II})$ can be reduced to $\mathrm{Cu}(\mathrm{I})$ in positive-ion mode electrospray mass spectrometry $[44,45]$.

The analytical performance of the proposed $\mathrm{Cu}^{2+}$ ion sensor was compared with some other reported selective sensors in related literature, and the results are presented in Table 2. Our sensor showed very good LOD (comparable or lower with some other recently reported fluorescent 
sensors), no interference by other competitive metal ions, instant response time, and wide $\mathrm{pH}$ range. The analytical results indicate that proposed peptide is a simple and highly sensitive fluorescent sensor for selective determination of $\mathrm{Cu}^{2+}$ ions in aqueous samples.

Table 2. Comparison of some recent fluorescent sensors for $\mathrm{Cu}^{2+}$ ions.

\begin{tabular}{|c|c|c|c|c|}
\hline Reference & LOD & Operation System & Reversibility & $\mathrm{pH}$ \\
\hline [17] & $120 \mathrm{nM}$ & $\begin{array}{c}\text { ON-OFF } \\
\text { (HEPES buffer) }\end{array}$ & - & $5.0-8.0$ \\
\hline [46] & $23.5 \mathrm{nM}$ & $\begin{array}{c}\text { ON-OFF } \\
\text { (HEPES buffer) }\end{array}$ & yes & $6.0-12.0$ \\
\hline [34] & $10.9 \mathrm{nM}$ & $\begin{array}{c}\text { ON-OFF } \\
\text { (PBS buffer) }\end{array}$ & - & $5.0-8.0$ \\
\hline [47] & $40.4 \mathrm{nM}$ & $\begin{array}{c}\text { OFF-ON } \\
\left(\mathrm{H}_{2} \mathrm{O}: \mathrm{CH}_{3} \mathrm{CN}, 1: 9 \mathrm{v} / \mathrm{v}\right)\end{array}$ & - & $5.0-7.0$ \\
\hline [48] & $15 \mathrm{nM}$ & $\begin{array}{l}\text { ON-OFF } \\
\text { (HEPES buffer) }\end{array}$ & yes & $7.0-12.0$ \\
\hline [49] & $1 \mu \mathrm{M}$ & $\begin{array}{l}\text { ON-OFF } \\
\text { (EtOH) }\end{array}$ & - & - \\
\hline [50] & $0.55-0.62 \mu \mathrm{M}$ & $\begin{array}{c}\text { ON-OFF } \\
\text { (phosphate buffer) }\end{array}$ & - & $7.0-11.0$ \\
\hline This work & $26.6 \mathrm{nM}$ & $\begin{array}{l}\text { ON-OFF } \\
\text { (MES buffer) }\end{array}$ & yes & $4.0-11.0$ \\
\hline
\end{tabular}

The symbol "-“ denotes that parameter was not tested or mentioned.

\section{Materials and Methods}

\subsection{Materials}

The chosen pentapeptides (EYHHQ, EHYHQ, EHHQY, and KYHHE) were synthesized using a procedure described previously [51] and were then chromatographically purified using gradient elution involving a water and a $10 \%$ to $100 \%(\mathrm{v} / \mathrm{v})$ acetonitrile containing $0.1 \%(\mathrm{v} / \mathrm{v})$ trifluoroacetic acid mixture in a $3.5 \mu \mathrm{m}, 3.0 \mathrm{~mm} \times 100 \mathrm{~mm}$ XBridgeShield RP18 column (purchased from Waters, Milford, MA, USA). The products were then characterized by mass spectrometry and an absorption peak at $214 \mathrm{~nm}$. Appropriate chromatograms and mass spectra confirming the purity and the identity of the investigated peptides are presented in Figures S9-Figure S12 in the Supplementary Materials. The concentration of the studied peptides was confirmed spectrophotometrically based on the absorbance and the value of molar extinction coefficient of tyrosine determined at $280 \mathrm{~nm}(\varepsilon=$ $\left.1280 \mathrm{M}^{-1} \mathrm{~cm}^{-1}\right)$ [52]. 2-(N-Morpholino)ethanesulfonic acid (MES) and the nitrate and chloride salts of the chosen metal cations $\left(\mathrm{Cu}^{2+}, \mathrm{Mn}^{2+}, \mathrm{Co}^{2+}, \mathrm{Ni}^{2+}, \mathrm{Zn}^{2+}, \mathrm{Cr}^{3+}, \mathrm{Cd}^{2+}, \mathrm{Ag}^{+}, \mathrm{Pb}^{2+}, \mathrm{Sr}^{2+}, \mathrm{Ba}^{2+}, \mathrm{Ca}^{2+}\right.$, $\mathrm{Mg}^{2+}, \mathrm{Al}^{3+}, \mathrm{Fe}^{2+}$, and $\mathrm{Ga}^{3+}$ ) were purchased from Sigma Aldrich (Poland; analytical grade or the highest purity available) and used without further purification. The solutions were prepared using ultra purified water (a conductivity not exceeding $0.18 \mu \mathrm{S} / \mathrm{cm}$ ) deionized by a Milli-QSP reagent water system (Merck Millipore, Burlington, MA, USA).

\subsection{Methods}

\subsubsection{UV Absorption Spectroscopy}

UV absorption spectra of EYHHQ, EHYHQ, EHHQY, and KYHHE (0.1 mM) with several $80 \mu \mathrm{M}$ metal cations $\mathrm{Cu}^{2+}, \mathrm{Mn}^{2+}, \mathrm{Co}^{2+}, \mathrm{Ni}^{2+}, \mathrm{Zn}^{2+}, \mathrm{Cr}^{3+}, \mathrm{Cd}^{2+}, \mathrm{Ag}^{+}, \mathrm{Pb}^{2+}, \mathrm{Sr}^{2+}, \mathrm{Ba}^{2+}, \mathrm{Ca}^{2+}, \mathrm{Mg}^{2+}, \mathrm{Al}^{3+}$, $\mathrm{Fe}^{2+}$, and $\mathrm{Ga}^{3+}$ ) were acquired at room temperature using a Perkin Elmer Lambda $650 \mathrm{UV} / \mathrm{Vis}$ spectrophotometer (Waltham, MA, USA) with a $1.0 \mathrm{~cm}$ quartz cell. The measurements were conducted in $5 \mathrm{mM}$ MES buffer ( $\mathrm{pH}$ 6.0). In performing UV absorption titration experiments, $2 \mathrm{~mL}$ of each $0.1 \mathrm{mM}$ 
peptide solution was titrated with twenty $1 \mu \mathrm{L}$ aliquots of $\mathrm{Cu}^{2+}$ solution at $8 \mathrm{mM}$ to achieve 1:0.8 peptide to metal ion molar ratio. Absorbance was measured at $275 \mathrm{~nm}$.

\subsubsection{Steady-State and Time-Resolved Fluorescence Spectroscopy}

Fluorescence emission spectra $\left(\lambda_{\mathrm{ex}}=275 \mathrm{~nm}\right)$ of EYHHQ, EHYHQ, EHHQY, and KYHHE $(0.1 \mathrm{mM})$ with several $80 \mu \mathrm{M}$ metal cations $\left(\mathrm{Cu}^{2+}, \mathrm{Mn}^{2+}, \mathrm{Co}^{2+}, \mathrm{Ni}^{2+}, \mathrm{Zn}^{2+}, \mathrm{Cr}^{3+}, \mathrm{Cd}^{2+}, \mathrm{Ag}^{+}, \mathrm{Pb}^{2+}, \mathrm{Sr}^{2+}, \mathrm{Ba}^{2+}\right.$, $\mathrm{Ca}^{2+}, \mathrm{Mg}^{2+}, \mathrm{Al}^{3+}, \mathrm{Fe}^{2+}$, and $\left.\mathrm{Ga}^{3+}\right)$ as well as all steady-state fluorescence intensity measurements were performed at room temperature on a Cary Eclipse Varian spectrofluorometer (Agilent, Santa Clara, CA, USA) equipped with a $1.0 \mathrm{~cm}$ quartz cell. In performing fluorescence titration experiments, $2 \mathrm{~mL}$ of each peptide solution at $0.1 \mathrm{mM}$ was titrated with twenty $1 \mu \mathrm{L}$ aliquots of $\mathrm{Cu}^{2+}$ solution at $8 \mathrm{mM}$ to achieve 1:0.8 peptide to metal ion molar ratio. Decreases in the fluorescence intensity were measured at $305 \mathrm{~nm}$, corresponding to the maximum of the peptide emission [53]. Possible absorption of light by the added cations at the excitation and emission wavelengths of peptides was measured. The influence of an inner filter effect was estimated on the basis of the following Equation (1):

$$
\mathrm{F}_{\text {corr }}=\mathrm{F}_{\mathrm{obs}} \times 10^{\frac{\mathrm{A}_{\mathrm{ex}}+\mathrm{Aem}}{2}}
$$

where $\mathrm{F}_{\mathrm{corr}}$ and $\mathrm{F}_{\mathrm{obs}}$ denote the corrected and observed fluorescence intensities, respectively, while $\mathrm{A}_{\mathrm{ex}}$ $+\mathrm{A}_{\mathrm{em}}$ is the sum of the absorbance of the peptide and ion measured at the excitation and emission wavelengths, respectively [54].

Time-resolved fluorescence experiments were conducted with a FluoTime 300 high-performance fluorescence lifetime spectrometer (PicoQuant, Berlin, Germany) at $20^{\circ} \mathrm{C}$. The probes were excited with the use of a pulsed LED of the PLS series $\left(\lambda_{\mathrm{ex}}=287 \mathrm{~nm}\right)$. The fluorescence lifetimes of all peptides $(0.1 \mathrm{mM})$ were determined in the absence and presence of increasing concentrations of $\mathrm{Cu}^{2+}$ ions up to $80 \mu \mathrm{M}$ at the wavelength corresponding to the maximum of the peptide emission $\left(\lambda_{\mathrm{em}}=305 \mathrm{~nm}\right)$.

Both steady-state and time-resolved experiments were conducted in $5 \mathrm{mM}$ MES buffer (pH 6.0).

\subsubsection{Analytical Procedure}

The limit of quantification (LOQ) was evaluated as the lowest point of a linear calibration plot (the plot of $\mathrm{F}_{0} / \mathrm{F}$ as a function of the concentration of $\mathrm{Cu}^{2+}$ ions) obtained with precision of $<10 \% \mathrm{RSD}$ and accuracy between 90 and $110 \%$, while limit of detection (LOD) was estimated as LOQ divided by three [55].

\subsubsection{NMR Spectroscopy}

The ${ }^{1} \mathrm{H}-\mathrm{NMR}$ spectra of $8 \mathrm{mM}$ EHYHQ alone and a mixture of $8 \mathrm{mM}$ EHYHQ and $4 \mathrm{mM} \mathrm{Cu}^{2+}$ (a 2:1 peptide to $\mathrm{Cu}^{2+}$ ions stoichiometric molar ratio was obtained from absorbance and fluorescence intensity measurements) were recorded at $25^{\circ} \mathrm{C}$ on a Varian Unity Inova $500(500 \mathrm{MHz})$ spectrometer (Agilent, Crawley, UK) at the Intercollegiate NMR Laboratory at the Technical University of Gdańsk (Poland) and analyzed with the SPARKY program [56]. The samples were dissolved in $90 \% \mathrm{H}_{2} \mathrm{O} / 10 \% \mathrm{D}_{2} \mathrm{O}$.

\subsubsection{Liquid Chromatography Coupled with Mass Spectrometry (LC-MS)}

Liquid chromatographic analyses were performed on an ultrahigh-performance liquid chromatography system Nexera (Shimadzu, Kyoto, Japan). Chromatographic conditions were as follows: a Kinetex column (Phenomenex, $1.7 \mu \mathrm{m}, \mathrm{C} 18,100 \AA, 2.1 \times 150 \mathrm{~mm}$ ), a flow rate of $0.3 \mathrm{~mL}$. $\mathrm{min}^{-1}$, and a gradient elution with $80 \%$ acetonitrile and water (from $0 \%$ to $40 \%$ acetonitrile). The column temperature was maintained at $25{ }^{\circ} \mathrm{C}$. The effluent was diverted to waste for $2 \mathrm{~min}$ after injection during each analysis. The liquid chromatographic system was coupled directly to a TripleTOF 5600+ (SCIEX, Framingham, MA, USA) mass spectrometer. Mass spectrometry was operated in positive mode at $200{ }^{\circ} \mathrm{C}$ with a needle voltage of $3000 \mathrm{~V}$ and with nitrogen as curtain gas and nebulizer gas. The declustering potential was $30 \mathrm{~V}$, and the collision energy was $7 \mathrm{~V}$. 


\section{Conclusions}

We have investigated the influence of the position of a tyrosine residue in selected peptides sequence on the binding properties with various transient metal ions. Among the four peptides studied, EHYHQ can selectively and sensitively detect $\mathrm{Cu}^{2+}$ ions over other common metal cations $\mathrm{Mn}^{2+}$, $\mathrm{Co}^{2+}, \mathrm{Ni}^{2+}, \mathrm{Zn}^{2+}, \mathrm{Cr}^{3+}, \mathrm{Cd}^{2+}, \mathrm{Ag}^{+}, \mathrm{Pb}^{2+}, \mathrm{Sr}^{2+}, \mathrm{Ba}^{2+}, \mathrm{Ca}^{2+}, \mathrm{Mg}^{2+}, \mathrm{Al}^{3+}, \mathrm{Fe}^{2+}$, and $\left.\mathrm{Ga}^{3+}\right)$ in the MES buffer, leading to a significant fluorescence quenching. The limit of detection of $\mathrm{Cu}^{2+}$ ions with the use EHYHQ was found to be approximately $27 \mathrm{nM}$. The binding stoichiometry of the resulting complexes with $\mathrm{Cu}^{2+}$ was evaluated, and their stability constant values were determined. Finally, the possible mechanism of the interactions between EHYHQ and $\mathrm{Cu}^{2+}$ ions was proposed.

Supplementary Materials: Supplementary materials can be found at http://www.mdpi.com/1422-0067/21/3/743/s1.

Author Contributions: Conceptualization: K.Ż., D.K., D.W., and J.M.; methodology: K.Ż., D.K., D.W., and J.M.; investigation, K.Ż., D.K., M.Z., and D.W.; writing—original draft preparation: K.Ż., D.K., M.Z., D.W., and J.M.; writing-review and editing: W.W. and L.C.; supervision: W.W. and L.C.; project administration: K.Ż. and D.W., J.M.; funding acquisition: K.Ż. All authors have read and agreed to the published version of the manuscript.

Funding: This research was funded by the Polish National Science Centre (NCN) under Grant No. 2016/23/D/ST4/01576.

Conflicts of Interest: The authors declare no conflict of interest. The funders had no role in the design of the study; in the collection, analyses, or interpretation of data; in the writing of the manuscript, or in the decision to publish the results.

\section{References}

1. Pesavento, M.; Alberti, G.; Biesuz, R. Analytical methods for determination of free metal ion concentration, labile species fraction and metal complexation capacity of environmental waters: A review. Anal. Chim. Acta 2009, 631, 129-141. [CrossRef] [PubMed]

2. Sun, L.; Hao, D.; Shen, W.; Qian, Z.; Zhu, C. Highly sensitive fluorescent sensor for copper (II) based on amplified fluorescence quenching of a water-soluble NIR emitting conjugated polymer. Microchim. Acta 2012, 177, 357-364. [CrossRef]

3. Cowan, J.A. Inorganic Biochemistry: An Introduction, 2nd ed.; John Wiley \& Sons: Hoboken, NJ, USA, 1997.

4. Lazarchick, J. Update on anemia and neutropenia in copper deficiency. Curr. Opin. Hematol. 2012, 19, 58-60. [CrossRef] [PubMed]

5. Bayindir, S. A simple rhodanine-based fluorescent sensor for mercury and copper: The recognition of $\mathrm{Hg}^{2+}$ in aqueous solution, and $\mathrm{Hg}^{2+} / \mathrm{Cu}^{2+}$ in organic solvent. J. Photochem. Photobiol. A Chem. 2019, 372, $235-244$. [CrossRef]

6. Liu, S.R.; Wu, S.P. An NBD-based sensitive and selective fluorescent sensor for copper (II) ion. J. Fluoresc. 2011, 21, 1599-1605. [CrossRef]

7. Gaggelli, E.; Kozlowski, H.; Valensin, D.; Valensin, G. Copper homeostasis and neurodegenerative disorders (Alzheimer's, prion, and Parkinson's diseases and amyotrophic lateral sclerosis). Chem. Rev. 2006, 106, 1995-2044. [CrossRef]

8. Yin, B.C.; Ye, B.C.; Tan, W.; Wang, H.; Xie, C.C. An allosteric dual-DNAzyme unimolecular probe for colorimetric detection of copper (II). J. Am. Chem. Soc. 2009, 131, 14624-14625. [CrossRef]

9. Chaiyo, S.; Siangproh, W.; Apilux, A.; Chailapakul, O. Highly selective and sensitive paper-based colorimetric sensor using thiosulfate catalytic etching of silver nanoplates for trace determination of copper ions. Anal. Chim. Acta 2015, 866, 75-83. [CrossRef]

10. Kaur, N.; Kumar, S. A diamide-diamine based $\mathrm{Cu}^{2+}$ chromogenic sensor for highly selective visual and spectrophotometric detection. Tetrahedron Lett. 2006, 47, 4109-4112. [CrossRef]

11. Becker, J.S.; Matusch, A.; Depboylu, C.; Dobrowolska, J.; Zoriy, M.V. Quantitative imaging of selenium, copper, and zinc in thin sections of biological tissues (Slugs-Genus Arion) measured by laser ablation inductively coupled plasma mass spectrometry. Anal. Chem. 2007, 79, 6074-6080. [CrossRef]

12. Doner, G.; Ege, A. Determination of copper, cadmium and lead in seawater and mineral water by flame atomic absorption spectrometry after coprecipitation with aluminum hydroxide. Anal. Chim. Acta 2005, 547, 14-17. [CrossRef] 
13. Herzog, G.; Arrigan, D.W. Application of disorganized monolayer films on gold electrodes to the prevention of surfactant inhibition of the voltammetric detection of trace metals via anodic stripping of underpotential deposits: Detection of copper. Anal. Chem. 2003, 75, 319-323. [CrossRef] [PubMed]

14. Moerner, W.E.; Fromm, D.P. Methods of single-molecule fluorescence spectroscopy and microscopy. Rev. Scient. Instrum. 2003, 74, 3597-3619. [CrossRef]

15. Chen, W.; Liu, X.; Chen, S.; Song, X.; Kang, J. A real-time colorimetric and ratiometric fluorescent probe for rapid detection of $\mathrm{SO}_{2}$ derivatives in living cells based on a near-infrared benzopyrylium dye. RSC Adv. 2015, 5, 25409-25415. [CrossRef]

16. Carter, K.P.; Young, A.M.; Palmer, A.E. Fluorescent sensors for measuring metal ions in living systems. Chem. Rev. 2014, 114, 4564-4601. [CrossRef] [PubMed]

17. Dai, Q.; Liu, H.; Gao, C.; Li, W.; Zhu, C.; Lin, C.; Tan, Y.; Yuan, Z.; Jiang, Y. A one-step synthesized acridine-based fluorescent chemosensor for selective detection of copper(II) ions and living cell imaging. New J. Chem. 2018, 42, 613-618. [CrossRef]

18. Han, J.; Tang, X.; Wang, Y.; Liu, R.; Wang, L.; Ni, L. A quinoline-based fluorescence "on-off-on" probe for relay identification of $\mathrm{Cu}^{2+}$ and $\mathrm{Cd}^{2+}$ ions. Spectrochim. Acta A 2018, 205, 597-602. [CrossRef]

19. Puangsamlee, T.; Tachapermpon, Y.; Kammalun, P.; Sukrat, K.; Wainiphithapong, C.; Sirirak, J.; Wanichacheva, N. Solvent control bifunctional fluorescence probe for selective detection of $\mathrm{Cu}^{2+}$ and $\mathrm{Hg}^{2+}$ via the excimer of pyrenylacetamide subunits. J. Luminesc. 2018, 196, 227-235. [CrossRef]

20. Raju, M.; Nair, R.R.; Raval, I.H.; Haldar, S.; Chatterjee, P.B. A water soluble $\mathrm{Cu}^{2+}{ }^{2}$-specific colorimetric probe can also detect $\mathrm{Zn}^{2+}$ in live shrimp and aqueous environmental samples by fluorescence channel. Sens. Act. $B$ Chem. 2018, 260, 364-370. [CrossRef]

21. Makowska, J.; Żamojć, K.; Wyrzykowski, D.; Wiczk, W.; Chmurzyński, L. Copper(II) complexation by fragment of central part of FBP28 protein from Mus musculus. Biophys. Chem. 2018, 241, 55-60. [CrossRef]

22. Tominaga, T.T.; Imasato, H.; Nascimento, O.R.; Tabak, M. Interaction of tyrosine and tyrosine dipeptides with $\mathrm{Cu}^{2+}$ ions: A fluorescence study. Anal. Chim. Acta 1995, 315, 217-224. [CrossRef]

23. Makowska, J.; Żamojć, K.; Wyrzykowski, D.; Żmudzińska, W.; Uber, D.; Wierzbicka, M.; Wiczk, W.; Chmurzyński, L. Probing the binding of $\mathrm{Cu}^{2+}$ ions to a fragment of the $\mathrm{A} \beta_{(1-42)}$ polypeptide using fluorescence spectroscopy, isothermal titration calorimetry and molecular dynamics simulations. Biophys. Chem. 2016, 216, 44-50. [CrossRef] [PubMed]

24. Kozłowski, H.; Kowalik-Jankowska, T.; Jeżowska-Bojczuk, M. Chemical and biological aspects of $\mathrm{Cu}^{2+}$ interactions with peptides and aminoglycosides. Coord. Chem. Rev. 2005, 249, 2323-2334. [CrossRef]

25. Hoernke, M.; Koksch, B.; Brezesinski, G. Amyloidogenic peptides at hydrophobic-hydrophilic interfaces: Coordination affinities and the chelate effect dictate the competitive binding of $\mathrm{Cu}^{2+}$ and $\mathrm{Zn}^{2+}$. ChemPhysChem 2011, 12, 2225-2229. [CrossRef]

26. Yip, T.T.; Nakagawa, Y.; Porath, J. Evaluation of the interaction of peptides with Cu(II), Ni(II), and Zn(II) by high-performance immobilized metal ion affinity chromatography. Anal. Biochem. 1989, 183, 159-171. [CrossRef]

27. Sigel, H.; Martin, R.B. Coordinating properties of the amide bond. Stability and structure of metal ion complexes of peptides and related ligands. Chem. Rev. 1982, 82, 385-426. [CrossRef]

28. Yang, H.; Liu, Z.Q.; Zhou, Z.G.; Shi, E.X.; Li, F.Y.; Du, Y.K.; Yi, Y.; Huang, C.H. Highly selective ratiometric fluorescent sensor for $\mathrm{Cu}(\mathrm{II})$ with two urea groups. Tetrahedr. Lett. 2006, 47, 2911-2914. [CrossRef]

29. Ma, D.L.; He, H.Z.; Chan, D.S.H.; Wong, C.Y.; Leung, C.H. A colorimetric and luminescent dual-modal assay for $\mathrm{Cu}(\mathrm{II})$ ion detection using an iridium(III) complex. PLoS ONE 2014, 9, e99930. [CrossRef]

30. Arabahmadi, R. A reversible fluorescence “ON-OFF-ON" sensor for sequential detection of $\mathrm{F}^{-}$and $\mathrm{Cu}^{2+}$ ions and its application as a molecular-scale logic device and security keypad lock. J. Coord. Chem. 2019, 72, 1187-1202. [CrossRef]

31. Fu, Y.; Feng, Q.C.; Jiang, X.J.; Xu, H.; Li, M.; Zang, S.Q. New fluorescent sensor for $\mathrm{Cu}^{2+}$ and $\mathrm{S}^{2-}$ in $100 \%$ aqueous solution based on displacement approach. Dalton Trans. 2014, 43, 5815-5822. [CrossRef]

32. Li, Z.; Zhang, L.; Wang, L.; Guo, Y.; Cai, L.; Yu, M.; Wei, L. Highly sensitive and selective fluorescent sensor for $\mathrm{Zn}^{2+} / \mathrm{Cu}^{2+}$ and new approach for sensing $\mathrm{Cu}^{2+}$ by central metal displacement. Chem. Commun. 2011, 47, 5798-5800. [CrossRef] [PubMed]

33. Formica, M.; Fusi, V.; Giorgi, L.; Micheloni, M. New fluorescent chemosensors for metal ions in solution. Coord. Chem. Rev. 2012, 256, 170-192. [CrossRef] 
34. Praikaew, P.; Maniam, S.; Charoenpanich, A.; Sirirak, J.; Promarak, V.; Langford, S.J.; Wanichacheva, N. Water-soluble $\mathrm{Cu}^{2+}$-fluorescent sensor based on core-substituted naphthalene diimide and its application in drinking water analysis and live cell imaging. J. Photochem. Photobiol. A Chem. 2019, 382, 111852. [CrossRef]

35. Yang, W.; Chen, X.; Su, H.; Fang, W.; Zhang, Y. The fluorescence regulation mechanism of the paramagnetic metal in a biological HNO sensor. Chem. Commun. 2015, 51, 9616-9619. [CrossRef] [PubMed]

36. Jung, H.S.; Kwon, P.S.; Lee, J.W.; Kim, J.I.; Hong, C.S.; Kim, J.W.; Yan, S.; Lee, J.Y.; Lee, J.H.; Joo, T.; et al. Coumarin-derived $\mathrm{Cu}^{2+}$-selective fluorescence sensor: Synthesis, mechanisms, and applications in living cells. J. Am. Chem. Soc. 2009, 131, 2008-2012. [CrossRef] [PubMed]

37. Bosque-Sendra, J.M.; Almansa-López, E.; García-Campaña, M.; Cuadros-Rodríguez, L. Data analysis in the determination of stoichiometries and stability constants of complexes. Anal. Sci. 2003, 19, 1431-1439. [CrossRef] [PubMed]

38. Gans, P.; Sabatini, A.; Vacca, A. HypSpec. 2008. Available online: http://www.hyperquad.co.uk (accessed on 16 August 2019).

39. Abbas, I.; Vranic, M.; Hoffmann, H.; El-Khatib, A.; Montes-Bayón, M.; Möller, H.; Weller, M. Investigations of the copper peptide hepcidin-25 by LC-MS/MS and NMR. Int. J. Mol. Sci. 2018, 19, 2271. [CrossRef]

40. Gaggelli, E.; D'Amelio, N.; Valensin, D.; Valensin, G. ${ }^{1} \mathrm{H}$ NMR studies of copper binding by histidine-containing peptides. Magn. Reson. Chem. 2003, 41, 877-883. [CrossRef]

41. Zoroddu, M.A.; Serenella, M.; Peana, M. Copper and nickel binding in multi-histidinic peptide fragments. J. Inorg. Biochem. 2009, 103, 1214-1220. [CrossRef]

42. De Ricco, R.; Potocki, S.; Kozłowski, H.; Valensin, D. NMR investigations of metal interactions with unstructured soluble protein domains. Coord. Chem. Rev. 2014, 269, 1-12. [CrossRef]

43. Deschamps, P.; Zerrouk, N.; Martens, T.; Charlot, M.F.; Girerd, J.J.; Chaumeil, J.C.; Tomas, A. Copper complexation by amino acid: L-glutamine-copper(II)-L-histidine ternary system. J. Trace Microprobe Tech. 2003, 21, 729-741. [CrossRef]

44. Gianelli, L.; Amendola, V.; Fabbrizzi, L.; Pallavicini, P.; Mellerio, G.G. Investigation of reduction of Cu(II) complexes in positive-ion mode electrospray mass spectrometry. Rapid Commun. Mass Spectrom. 2001, 15, 2347-2353. [CrossRef]

45. Lavanant, H.; Virelizier, H.; Hoppilliard, Y. Reduction of copper(II) complexes by electron capture in an electrospray ionization source. J. Am. Soc. Mass Spectrom. 1998, 9, 1217-1221. [CrossRef]

46. An, Y.; Wang, P.; Yue, Z. A sequential and reversibility fluorescent pentapeptide probe for $\mathrm{Cu}(\mathrm{II})$ ions and hydrogen sulfide detections and its application in two different living cells imaging. Spectrochim. Acta A Mol. Biomol. Spectrosc. 2019, 216, 319-327. [CrossRef]

47. Kaewnok, N.; Petdum, A.; Sirirak, J.; Charoenpanich, A.; Panchan, W.; Sahasithiwat, S.; Sooksimuang, T.; Wanichacheva, N. Novel $\mathrm{Cu}^{2+}$-specific "Turn-ON" fluorescent probe based on [5] helicene with very large Stokes shift and its potential application in living cells. New J. Chem. 2008, 42, 5540-5547. [CrossRef]

48. Wang, P.; Wu, J. Highly selective and sensitive detection of $\mathrm{Zn}$ (II) and $\mathrm{Cu}(\mathrm{II})$ ions using a novel peptide fluorescent probe by two different mechanisms and its application in live cell imaging. Spectrochim. Acta A Mol. Biomol. Spectrosc. 2019, 208, 140-149. [CrossRef]

49. Seo, H.; An, M.; Kim, B.Y.; Choi, J.H.; Helal, A.; Kim, H.S. Highly selective fluorescent probe for sequential recognition of copper (II) and iodide ions. Tetrahedron 2017, 73, 4684-4691. [CrossRef]

50. Lu, M.C.; Chiu, L.Y.; Chiu, L.Y.; Lin, C.Y.; Horng, J.C. Highly selective and water-soluble peptidyl chemosensors for copper(ii) and mercury(ii) ions based on a $\beta$-hairpin structure. Anal. Meth. 2013, 5, 1702-1707. [CrossRef]

51. Uber, D.; Wyrzykowski, D.; Tiberi, C.; Sabatino, G.; Żmudzińska, G.; Chmurzyński, L.; Papini, A.M.; Makowska, J. Conformation-dependent affinity of $\mathrm{Cu}$ (II) ions peptide complexes derived from the human Pin1 protein. J. Therm. Anal. Calorim. 2017, 127, 1431-1443. [CrossRef]

52. Pelton, J.T.; McLean, L.R. Spectroscopic methods for analysis of protein secondary structure. Anal. Biochem. 2000, 277, 167-176. [CrossRef]

53. Lakowicz, J.R. Principles of Fluorescence Spectroscopy, 3rd ed.; Springer Science \& Business Media: Berlin, Germany, 2013.

54. Żamojć, K.; Wiczk, W.; Chmurzyński, L. The influence of the type of substituents and the solvent on the interactions between different coumarins and selected TEMPO analogues-Fluorescence quenching studies. Chem. Phys. 2018, 513, 188-194. [CrossRef] 
55. Żamojć, K.; Zdrowowicz, M.; Hać, A.; Witwicki, M.; Rudnicki-Velasquez, P.B.; Wyrzykowski, D.; Wiczk, W.; Chmurzyński, L. Dihydroxy-substituted coumarins as fluorescent probes for nanomolar-level detection of the 4-amino-TEMPO spin label. Int. J. Mol. Struct. 2019, 20, 3802. [CrossRef] [PubMed]

56. Goddard, T.D.; Kneller, D.G. SPARKY3. 2002. Available online: https://omictools.com/sparky-tool (accessed on 5 November 2019).

(C) 2020 by the authors. Licensee MDPI, Basel, Switzerland. This article is an open access article distributed under the terms and conditions of the Creative Commons Attribution (CC BY) license (http://creativecommons.org/licenses/by/4.0/). 